\title{
ERRATA, VOLUME 73
}

M. J. Fisher, Singular integrals on Hilbert space, pp. 428-431.

Page 429: In the third line of the statement of Theorem 1 replace $a \in \log ^{+} L\left(H, n \circ B^{-1}\right)$ by $a \in L \log ^{+} L\left(H, n \circ B^{-1}\right)$.

Page 431: Reference 2 should read:

M. J. Fisher, Singular integrals on Hilbert space, Ph.D. Thesis, Cornell University, Ithaca, New York, 1966.

M. S. Berger, On nonlinear perturbations of the eigenvalues of a compact self-adjoint operator, pp. 704-708.

Page 707, Line 3: $A x$ in equation (4) should read $-A x$.

\section{STATEMENT OF OWNERSHIP, MANAGEMENT AND CIRCULATION}

Act of October 23, 1962: Section 4369, Title 39, United States Code

1. Date of Filing: September 27, 1967

2. Title of Publication: Bulletin of the American Mathematical Society

3. Frequency of issue. Six times per year

4. Location of Known Office of Publication: P. O. Box 6248, Providence, Rhode Island 02904

5. Location of the Headquarters or General Business Offices of the Publishers: Same

6. Names and Addresses of Publisher, Editor, and Managing Editor. Publisher: American Mathematical Society, P. O. Box 6248, Providence, Rhode Island 02904. Editor: Felix Browder, Chairman of the Editorial Committee, P. O. Box 6248, Providence, Rhode Island 02904. Managing Editor: None

7. Owner: None

8. Known Bondholders, Mortgagees and Other Security Holders Owning or Holding 1 Percent or More of Total Amount of Bonds, Mortgages or Other Securities: None

9. Paragraphs 7 and 8 include, in cases where the stockholder or security holder appears upon the books of the company as trustee or in any other fiduciary relation, the name of the person or corporation for whom such trustee is acting, also the statements in the two paragraphs show the affiant's full knowledge and belief as to the circumstances and conditions under which stockholders and security holders who do not appear upon the books of the company as trustees, hold stock and securities in a capacity other than that of a bona fide owner. Names and addresses of individuals who are stockholders of a corporation which itself is a stockholder or holder of bonds, mortgages or other securities of the publishing corporation have been included in paragraphs 7 and 8 when the interests of such individuals are equivalent to 1 percent or more of the total amount of the stock or securities of the publishing corporation.

I certify that the statements made by me above are correct and complete.-Gordon L. Walker 